\title{
A VEZETŐI SZÁMVITEL ALKALMAZÁSÁNAK SZÜKSÉGESSÉGE A MEZŐGAZDASÁGBAN
}

Napjainkban a mezốgazdasági vállalkozások vezetésében már elengedhetetlen a controlling és az ahhoz szorosan kapcsolódó vezetôi számvitel alkalmazása. A hosszú távú eredményes múködéshez és a versenyképességhez nélkülözhetetlen a jövőorientált vezetói gondolkodás és a jól elókészített, gyors döntések meghozatalának képessége. A vezetói számvitel nélkülözhetetlen szerepet játszik a vállalatok sikereiben, alkalmazása egyértelmúen növeli a jövedelmezóséget (Kittredge, 2004). Alkalmazása ezenkívül hozzásegíti a vállalkozásokat egyéb alapvető céljaik - mint például a megfelelő készletezés, hatékony erôforrás-felhasználás, fizetốképesség fenntartása, nyereséges gazdálkodás - eléréséhez is (Sabján - Sutus, 2003). A mezógazdaság, a biológiai és természeti tényezóknek köszönhetôen, egy speciálisan kockázatos nemzetgazdasági ág, amely jelentốs kezdeti tốkeberuházást igényel, ezért itt különös szükség van a megfelelố pénzügyi és stratégiai tervezésre és a vállalkozás jövôbeni helyzetének megbízhatóbb ismeretére.

Kulcsszavak: vezetối információk, vállalatirányítás, döntéshozatal, vezetôi számvitel, mezốgazdaság, Európai Unió, FADN

Ahogy Magyarország gyorsan változó gazdaságában a termelés helyett egyre inkább a piaci orientáció válik meghatározóvá, változik a vállalaton belüli információigény is, és ebben a folyamatban a vállalat pénzügyi szakembereinek mind fontosabb szerepet kell játszaniuk. A hangsúly arra tolódik, hogy olyan információval lássák el a vezetést, amely segíti a tisztánlátásban, és amely alapján képessé válik a jövőre vonatkozó tervezésre. A számviteli adatok ilyen célú felhasználását nevezik „vezetói számvitel”-nek, amely fogalom fedi azokat a számviteli módszereket, rendszereket és technikákat, amelyek speciális tudással és képességekkel párosulva segítik a vezetést a profit maximalizálásában vagy a veszteség minimalizálásában (Grimshaw, 1993). A legtöbben a vezetôi számvitel fogalmán ma is a pénzügyi számvitelt értik, amely arra hivatott, hogy múltbeli adatok alapján informálja a vállalaton kívüli felhasználókat a cég aktuális vagyoni, jövedelmi és pénzügyi helyzetéról (Laáb, 1998). Ezzel ellentétben a vezetôi számvitel elsődleges célja a vezetôi réteg támogatása a rövid és hosszú távú döntéshozatalban. A múltbeli információk közlésével szemben a vezetói számvitel a vállalat jövő́beni tevékenységére fókuszál, becsléseket, előrejelzéseket is felhasználva. Hazánkban ma sok vállalkozás napi gondokkal gyötródik, a legjobbak is alig mernek tervezgetni, mert úgy érzik, nem mérhető fel saját erejük. A vezetói számviteli módszer erre a felmérésre ad lehetőséget, $s$ ha majd erősödik a piac, fellendül a termelés, még nagyobb biztonságot nyújt a jövő, a fejlesztés megtervezésében (Nagy, 1993).

Talán a fent leírt „fogalomzavarnak” is köszönhetô, hogy a vezetối számvitel alkalmazása a magyar vállalkozásoknál még jelenleg is - mintegy másfél évtizeddel a rendszerváltás után - kezdetlegesnek mondható. A vállalatokat vezetőik az irányításkor sokszor külön funkcionális vagy termékszintú megbontásokban kezelik, nem pedig holisztikus módon, tehát egységes egészként, amelynek minden egyes része kihatással van a többire. Különösen igazak ezek a mezőgazdasági szektorra, ahol 1989 után gyakran maguk a termelésben is részt vevő gazdák váltak a közép- és nagyméretû́ vállalkozások vezetôivé, menedzsereivé. Ez a réteg inkább a mezőggazdálkodási tevékenység ellátásához szükséges ismeretekkel rendelkezik, amely nem elégíti 
ki szükségszerúen a mai modern piacgazdaság által a vállalatok vezetésével, irányításával és ellenôrzésével szemben támasztott követelményeket. Számukra egyre nagyobb gondot jelent a túlélés, a gyorsan változó környezethez való alkalmazkodás. Ezenfelül a mezógazdaságnak, mint nemzetgazdasági ágnak, számos olyan jellegzetessége van, amelyek miatt az ágazat különösen nagy kockázatú. Ezeket a kockázatokat megfelelő hosszú és rövid távú tervezés, folyamatos gazdaságipénzügyi ellenôrzés és elemzések nélkül rendkívül nehéz kezelni.

\section{A vezetôi számvitel fogalma}

Mindenekelőtt szeretném bemutatni a vezetôi számvitel által létrehozott, döntésmegalapozó információk elhelyezkedését egy vállalat belsô információs csatornái között. Az 1. ábra jól szemlélteti, hogy a vezetôi számviteli rendszerek önmagukban nem biztosítják a vállalkozás számára a hatékony, profitmaximalizáló múködést és a versenyelőnyt. Sokkal inkább a többi információs csatornával együtt, azokat átfogva, velük összhangban és egymást kiegészítve tudnak létfontosságú alapot nyújtani a tervezéshez, a döntéshozatalhoz, a szervezéshez és az ellenőrzéshez.
Általánosságban elmondható, hogy a vonatkozó irodalmi források a vezetôi számvitel alatt egy rendszerelméletben kialakított szervezési, tervezési, elszámolási, értékelési és információszolgáltatási rendszert értenek (Körmendi - Tóth, 2002). A vezetôi számvitel öszszes lényeges elemének, vonásának a megismeréséhez azonban bemutatok néhány konkrét meghatározást.

Engler (1990) szerint a vezetôi számvitel arra specializálódott, hogy olyan információkat nyújtson egy vállalat vezetőinek, amelyeket azok hasznosnak találnak a belsô döntéshozatal során. Így a vezetôi számvitelnek olyan információkat kell szolgáltatnia, amelyek segítik a menedzsereket az öt alapvető feladatuk - tervezés, szervezés, alkalmazottakkal kapcsolatos feladatok, vezetés és ellenőrzés - végrehajtásában. Ez a megfogalmazás különös hangsúlyt fektet a vezetôi számvitel menedzsmentet támogató funkciójára. Az információk tulajdonságait nézve azonban, véleményem szerint, nem jelenik meg egyértelmúen az információknak a számviteli rendszer által való generálásának a feltétele.

Meglátásom szerint a fogalmat legpontosabban körülhatároló definíció az okleveles vezetői számviteli szakembereket magába tömörítő nemzetközi szervezet, a CIMA (Chartered Institute of Management Accountants) meghatározása. Eszerint a vezetói szám-

A vezetést támogató belsố információs csatornák modellje

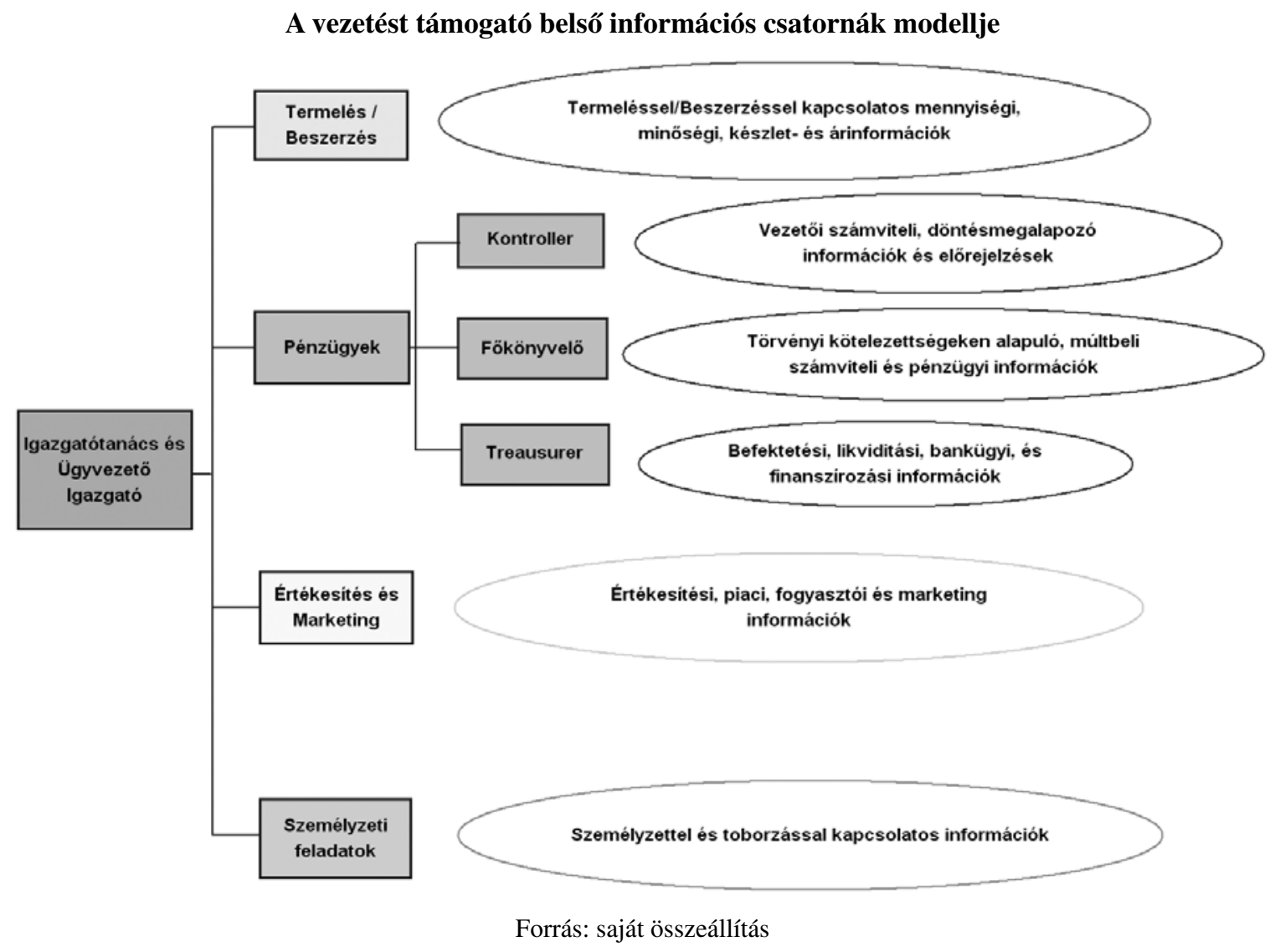


vitel a számviteli és a pénzügyi menedzsment alapelveinek alkalmazását jelenti a vállalat értékteremtésének, az értékek megőrzésének és növelésének érdekében. A vezetôi számvitel a menedzsment szerves része, amely az alábbiakban felsorolt tevékenységekhez felhasznált információk beazonosításával, bemutatásával és értelmezésével foglalkozik:

- üzleti stratégiaalkotás,

- tervezó és ellenőrző tevékenységek,

- döntéshozatal,

- optimális eróforrás-felhasználás,

- a vállalaton belüli és kívüli felhasználók tájékoztatása,

- teljesítményjavítás és értéknövelés,

- a vállalat vagyonainak a védelme,

- vállalati vezetés és belsố ellenőrzés.

Mindez a menedzsmentben való olyan részvételt feltételez, amely hatékonyan biztosítja a következőket:

- a vállalat hosszú távú céljainak elérését szolgáló tervek létrehozása (stratégiai tervezés),

- a vállalat rövid távú múködését elősegítő tervek megalkotása (költség- és eredménytervezés),

- beszerzés, finanszírozás (pénzügyi menedzsment) és a tranzakciók rögzítése, dokumentálása (pénzügyi számvitel),

- a pénzügyi és múködési információk bemutatása,

- a terveket és az eredményeket összhangba hozó korrekciós tevékenységek (pénzügyi ellenôrzés),

- a vállalat rendszereinek és múködésének vizsgálata, jelentések készítése (belsô ellenôrzés, menedzsmentaudit).

A vezetôi számvitel fô feladata lényegében az adatok beszerzése - külsố vagy belső forrásból -, elemzése, feldolgozása, értelmezése és az eredmények kommunikálása belsố célokra való felhasználáshoz, hogy a felső vezetés ez által eredményesebben tervezzen, hozzon döntést és kontrolálja a múködést (Lucey, 1996).

A fentiek nyomán a vezetói számvitel fogalmát - saját meghatározásommal - a következóképpen írom le. A vezetói számvitel olyan információs rendszer, amely a vállalat vezetốit látja el a döntéseik meghozatalához hasznos információkkal, ahol

- az információk a számviteli rendszer által jöttek létre,

- az információs rendszer az input adatok beszerzése, feldolgozása, elemzése, értelmezése és kommunikálása által képes a vezetók számára hasznos adatokat elóállítani,

- a vállalat vezetối az információkat hasznosítva hozzák meg a stratégiaalkotáshoz, az operatív múködés tervezéséhez, a vállalati ellenôrzéshez, a legkedvezóbb erőforrás- allokációhoz, a jelentések elkészítéséhez, a teljesítmények javításához, a vagyonok védelméhez és az értékek növeléséhez szükséges rövid és hosszú távú döntéseiket.

Így véleményem szerint vezetôi számvitelnek tekinthetjük például azt is, ha egy gazdálkodó többnyire számviteli adatokat felhasználva, bármilyen jellegú gazdaságossági számításokat, kalkulációkat végez annak érdekében, hogy ezzel saját vállalkozásának a jövốbeni hatékonyságát, nyereségességét és versenyképességét segítse elő.

Végül a vezetôi számvitel fogalmánál szükségesnek tartom leírni annak funkcióit is, amelyek végsố soron a vezetés feladataihoz kapcsolódnak. Így a vezetôi számvitel klasszikus funkciói végső soron a döntéshozatal támogatása, illetve a tervezés, ellenőrzés és a teljesítménymérés kiszolgálása.

\section{A vezetői számvitel bázisai}

A vezetói számvitel alapjának az általa felhasznált információkat tekinthetjük. Döntéshozatali szempontból ezekkel az információkkal szemben alapvetố követelmény a relevancia és a megbízhatóság. Ezenkívül további korlátozó feltételként jelenik meg az idôszerúség, a költség-haszon elve, illetve az információkkal kapcsolatos minőségi jellemzók egyensúlyának megőrzése. A vezetôi számvitel jelenlegi, aktuális, illetve tervezett, becsült és előrejelzett információkat használ fel. Az információk irányultsága tehát jellemzóen jövőbeli, szemben a pénzügyi számvitellel, ahol az információk irányultsága múltbeli, és tipikusan historikus és viszszaigazolható tényadatokat használ fel. A felhasznált információk gyakorlatilag két forrásból származhatnak: belsố, illetve külsố forrásból. Belsố információs források közé tartoznak értelemszerúen a vállalat egyes részlegei, mint például a pénzügyi-számviteli részleg, a termelő vagy beszerzési részleg, a raktározási részleg, a marketingrészleg stb., valamint a vállalat felsővezetối által létrehozott alapadatok. Külsô források között kell számításba vennünk az egyes statisztikai adattárak információit (pl. KSH, OECD, FAO), kimutatásait, az újságokat, szaklapokat, az árutőzsdei várakozásokat, továbbá az egyes speciális szakterületekhez kötődő információs rendszereket, hálózatokat (pl. CAPRI Common Agricultural Policy Regional Impact Analysis - modellek).

Ilyen információs rendszer többek között a mezőgazdasági számvitel területén az Európai Unió Mezőgazdasági Számviteli Információs Hálózata (FADN, Farm Accountancy Data Network), amely egy európai 
szinten múködő, kifejezetten a mezőgazdasági vállalkozásokra vonatkozó információs rendszer, és az azzal kapcsolatban lévô, a Magyarországról történő adatszolgáltatás alapját képezó tesztüzemi rendszer (Kapronczai, 2003). Véleményem szerint a két rendszernek kiemelkedố jelentősége van a vezetói számvitel mezőgazdaságban való alkalmazásának szempontjából, szoros összefüggés rajzolódik ki ugyanis az FADN (vagyis Magyarországon a tesztüzemi rendszer) számára szolgáltatandó - illetve az abból nyerhetô - és a vezetối számvitel gyakorlatban való alkalmazásához felhasználható adatok között.

A rendszert 1965-ben hozták létre, azzal a céllal, hogy betekintést nyerjen a tagországok mezőgazdasági vállalkozásainak jövedelmezóségi és pénzügyi helyzetébe. Legfontosabb szerepe, hogy olyan megbízható és reprezentatív információkat szolgáltasson az európai mezógazdasági teljesítményekről, amelyek pozitív segítséget nyújtanak az Európai Bizottság döntéseinek meghozatalához, illetve megfelelő alapot szolgáltatnak a hatékonysági elemzésekhez, hatásvizsgálatokhoz, egyéb számításokhoz és kalkulációkhoz, melyeket az agrárpolitikai intézkedések területén hasznosít az európai menedzsment. (Pl. ezek az adatok képezik a mezőgazdasági termények közösségi szintû árazásának alapját is [79. sz. Tanácsi rendelet, 1965]). A kiválasztott gazdaságok önkéntesen csatlakoznak a hálózathoz, és vállalják, hogy egységes könyvelést vezetnek, valamint adataikat - az adatvédelemre vonatkozó szabályok szigorú betartása mellett - agrárpolitikai célokra rendelkezésre bocsátják (Kovács, 2001, Keszthelyi et al., 1998). A rendszerbe történő adatszolgáltatás a gazdák saját érdeke, hiszen versenyelônyökhöz jutnak egyrészt azáltal, hogy a szolgáltatott adatokat saját vállalkozásukhoz is fel tudják használni vezetôi információként, másrészt azáltal, hogy hozzáférésük van a rendszerben lévố más, hasonló típusú gazdaságok összesített (tehát nem egyedi), elemzett adataihoz, amelyek szintén értékes alapul szolgálhatnak további vezetôii elemzések elkészítéséhez. Éppen ez a versenyelőny az oka annak, hogy Hollandiában például egy-egy vállalkozás maximum hét évig tartozhat az FADN-körbe. Hét év után ugyanis már olyan jelentôs a rendszerból származó információk felhasználásából adódó előnyük, hogy a további rendszertagságuk sértené a reprezentativitás elvét.

Egy holland kutatás azt vizsgálta az FADNrendszerrel kapcsolatban, hogy a vezetói számviteli információk felhasználásának milyen hatása lehet hosszabb távon a cserepesnövény-gazdaságoknál a profitra és az eróforrás-felhasználásra. A kutatás szerint a menedzsmentinformációk felhasználása jelen- tôs megtakarításokat eredményezett az anyagköltség és az igénybe vett szolgáltatások területén. Ez arra enged következtetni, hogy a gazdaságokban javult a hatékonyság, és több szolgáltatás igénybevételét is kiváltotta a vezetôi információk birtoklása. Az energiafelhasználás ugyan növekedett a vizsgált gazdaságoknál, ez azonban valószínúsíthetốen a vezetôi információk ideiglenes félreértelmezésének köszönhető, vagy annak, hogy a gazdák megpróbálták átformálni a felhasznált eróforrások szerkezetét, de nem energiagazdaságos módon (Csajbók et al., 2005). Ebból az a tanulság, hogy az FADN-rendszerben szükség van az onnan nyerhetố információk felhasználására vonatkozó útmutatóra, illetve az információk magyarázatára, gazdasági értelmének a leírására is. Ami a nyereségességet illeti, a vizsgálat azt állapította meg, hogy bár rövid távon átlagosan nem nőtt a gazdaságok profitja - ezt például az átszervezési költségek is okozhatták -, hosszú távon a nyereségesség javulása egyértelmúen megfigyelhetố volt. Továbbá nőtt a gazdaságokban használt gépállományok és egyéb befektetések értéke is, ami azt mutatja, hogy a vezetői információk felhasználásával lehetôség nyílt a termelés nagyobb volumenre állítására is. Összességében tehát a vezetői információk felhasználása egyértelmúen pozitívan hatott a vállalkozások hosszú távon való nyereségességére.

\section{A vezetối számvitel meghatározó területei a mezógazdaságban}

Ahhoz, hogy megértsük a vezetói számvitel alkalmazási lehetőségeit a mezőgazdaságban, tisztán kell látnunk, hogy a gazdák szokásaival, emberi jellemzóivel nehezen egyeztethetô össze a számvitelben elvárt messzemenó pontosság és írásos dokumentumokkal való alátámaszthatóság (Stone, 1968). Ezt hívhatjuk a vezetói számvitel mezőgazdaságban való alkalmazásának az emberi tényezóboól eredô sajátosságának. Biológiai tényezóből és természeti tényezôkből eredô sajátosságnak pedig azt tekinthetjük, hogy a termelés élő anyaggal (növényekkel, állatokkal) dolgozik, illetve a természeti tényezóktôl (termőföld minôsége, a földfelszín tagoltságát [domborzat], az éghajlati környezet stb.) függóen rendkívül nagy szórása lehet a hozamoknak, míg a termelés ráfordításai nem a hozamok függvényében alakulnak. E tényezốk hatása tehát az egész mezőgazdasági termelésben érvényesül, az üzemszervezés minden egyes területénél figyelembe kell óket venni, következésképpen a vezetôi számviteli elemzések eredményeinek értelmezésénél is tekintettel kell rájuk lenni. 


\section{Üzemszervezési sajátosságokból eredó feladatok}

Célszerú kiemelni a mezőgazdaság néhány konkrét, az üzemszervezéssel, számviteli elszámolással, számbavétellel, vezetôi információs rendszerek kialakításával, múködtetésével kapcsolatos jellemzőjét, amelyek mind speciális kihívások elé állítják az ezen a területen múködő vezetôi számviteli szakembereket:

- A mezőgazdasági termelés sajátosságaiból eredően fontos feladat a környezet védelme, ez maga után vonhat extra költségeket vagy beruházásokat.

- A mezôgazdasági termelés nagy mennyiségú és nagy értékú, sokféle erôforrás felhasználását igényli, jelentôs kezdeti tốkeberuházásra van szükség. Továbbá a beruházások nagy része hoszszú távú befektetést igényel (például a termőre fordulás akár több évbe is beletelhet), így számolni kell a pénz időértékével (Véry, 2001).

- Az előállított növényi és állati termékek közvetlenül csak részben alkalmasak emberi táplálkozásra (vagyis azonnali értékesítésre), nagy hányaduk például a takarmányok - belsố hasznosításra kerül, más részüket pedig előfordulhat, hogy egyáltalán nem hasznosítják.

- A termelésre - 1́gy közvetetten az értékesítésre is jellemzô a szakaszosság, az idényszerúség, egyes folyamatok idóhöz kötöttek, amit a folyamatok szervezésében, irányításában, az eróforrások rendelkezésre állításában, illetve a kapacitáskihasználásban figyelembe kell venni.

- Az előállított termékek, termények jelentôs hányada gyorsan romló, ez nagy szállítási és feldolgozási kapacitást igényel.

- A munkaerő mint erőforrás kihasználása során figyelembe kell venni például, hogy a munkavégzés természethez kötött, attól el nem szakítható, a munkák jelentôs része a szabadban, az idôjárás változásainak kitéve, térben kiterjedt területen folyik, a munkacsúcsok idején a napi munkaidő általában hosszabb, pihenőnapok nincsenek.

- A természeti károk (aszály, belvíz) jelentős gazdasági-pénzügyi kárral járnak.

\section{A befektetett és a forgóeszközökkel kapcsolatos sajátosságok}

A mezőgazdaságban sajátos befektetett eszköz a termőföld, amely nélkülözhetetlen és elengedhetetlen feltétele a mezőgazdasági termelésnek. Ezenkívül tőkemegôrző és kincsképző szerepet is betölt, mert korlátozottan áll rendelkezésre, nem szaporítható, emberi munkával elő nem állítható sajátos vagyontárgy (Sabján - Sutus, 2003). A termóterületekhez fontos ökológiai kérdések is kapcsolódnak, mint például a természetvédelem, a termóképesség fokozása, a termôterület hasznosítása, a talajvédelem, a környezetvédelem stb. A föld különböző, nem mezőggazdasági tevékenységeknek is üzleti tere. A mezógazdaságban a befektetett eszközök közül a tárgyi eszközök nemcsak a termelés lehetőségeit, kereteit teremtik meg, de a mezőgazdasági árutermék közvetlen elóállítói is (például ültetvények, tenyészállatok).

Míg a tárgyi eszközök a termelés lehetőségét, addig a forgóeszközök annak tényleges mennyiségét határozzák meg. Folyamatosan csak a szükséges forgóeszközállománnyal lehet gazdálkodni. A forgóeszközökkel való takarékosság a vállalkozás szempontjából nem mindig tartozik a jó döntések közé, mert itt - a mezôgazdaságban - a forgóeszközök hiánya hozamkieséssel járhat. Ezt a helyzetet tovább súlyosbíthatja a forgóeszközök nem megfelelő összetétele, valamint a felhasználásuk nem kielégítő hatékonysága.

A mezőgazdasági vállalkozások készletgazdálkodásánál több sajátosságra is tekintettel kell lenni:

- bizonyos készleteket (például vetőmagokat, növényvédő szereket, mútrágyákat stb.) csak meghatározott idôszakokban használnak fel a termelés idényszerüségére visszavezethető okokból,

- a termeléshez egyidejúleg vásárolt és saját előállítású készleteket is felhasználnak,

- a készletek jelentôs részénél nagy gondot kell fordítani a tárolásra, mert az idôjárás és más külsố hatások jelentôs minőségromlást is okozhatnak,

- kiemelten sajátos mezógazdasági készlet a mezei leltár, mint a növénytermesztés befejezetlen termelése, továbbá a növendék-, hízó- és egyéb állatok (a tenyészállatokat a számviteli törvény szerint a tárgyi eszközök között mutatjuk ki), illetve állati termékek.

\section{Önköltségszámítás a mezógazdaságban}

A vezetối számvitel egyik legalapvetốbb kalkulációja az önköltség kiszámítása, amellyel megállapítható egy termék vagy szolgáltatás várható, tervezett vagy tényleges előállítási költsége. A mezőgazdasági ágazatok önköltségszámítása eltér más nemzetgazdasági ágak gyakorlatától, mert a mezőgazdasági termelés sajátosságainak, illetve a mezőgazdasági termelés vertikális felépítésének meg kell jelennie az önköltségszámításban is. Az önköltség kiszámítása két okból is szükséges a mezőgazdasági vállalkozásoknál, vagyis az önköltségi mutatónak kettős funkciója van. Egyrészt a saját termelésú készletek értékeléséhez használható azáltal, hogy „kifejezi az újonnan létrehozott termék 
értékét”, másrészt ,arról ad képet, hogy mibe került az adott vállalatnak egyik vagy másik fajta termék", vagyis az ágazatok különbözô eredményességi vizsgálatait teszi lehetővé (Erdei, 1965).

$\mathrm{Az}$ önköltségszámítás témakörében felvetődik a kérdés: utókalkuláció vagy norma szerinti kalkuláció? Erre a kérdésre Sutus Imre egyik cikke (1992) alapján adható meg a válasz. A norma szerinti közvetlen önköltség az egységnyi termék előállításához szükséges, a termékhez rendelt, meghatározott költség. A norma szerinti közvetlen önköltség megállapítása aktualizált ráfordítási normák létét feltételezi. A ráfordítási normák természetesen múszakilag megalapozott, naprakész, folyamatosan karbantartott normák. A ráfordítási normák mellett ugyanolyan fontos, hogy a hozamok is norma szerint meghatározhatók legyenek. Egyértelmú, hogy a ráfordítási normák mellett a hozamok normái azért fontosak, mert bármilyen önköltség megállapítása csak úgy történhet, hogy az előállítási költségeket elosztjuk a megtermelt termék mennyiségével. Itt jutottunk el a hozamok - a termékek mennyisége - kérdéséhez. Ezenkívül már fentebb is szó volt róla, hogy a mezőgazdaságnak két olyan sajátossága is van, amelyek alapvetően befolyásolják az önköltség mindkét elemét: a biológiai és a természeti tényezók. Az eddig leírtak eléggé meggyőzóen bizonyítják, hogy a mezőgazdasági termékek önköltségének megállapítására általában nem célszerú a normatív önköltség-számítási módszert alkalmazni. A gyakorlatban egyébként a vállalatok nem is választják a norma szerinti kalkulációt, tekintettel arra is, hogy a számviteli törvény a vállalatok nagyobb része számára egyértelmúen az utókalkulációs módszert írja elő. (Ez alól csak azok a vállalatok mentesülnek, ahol az értékesítésnek az eladott áruk beszerzési értékével, a közvetített szolgáltatások értékével csökkentett nettó árbevétele valamely üzleti évben az egymilliárd forintot vagy a költségnemek szerinti költségek együttes összege az ötszázmillió forintot nem haladja meg.)

A következő kérdés ezek után az, hogy az utókalkuláció alapján számított közvetlen önköltség mit tartalmazhat, milyen költségeket foglalhat magába. A számviteli törvény szerint:

„Az eszköz előállítási értékének részét azok a költségek képzik, amelyek

- az eszköz (termék) előállítása, üzembe helyezése, bővítése, rendeltetésének megváltoztatása, átalakítása, helyreállítása során közvetlenül felmerültek,

- az előállítással bizonyíthatóan szoros kapcsolatban voltak, továbbá
- az eszközre (termékre) megfeleló mutatók, jellemzók segítségével elszámolhatók (együttesen: közvetlen önköltség)" (C. törvény a Számvitelrôl, 2000).

A közvetlen önköltség megállapításánál a kiindulási alap az, hogy itt a költségnemek számlaosztályból (5. számlaosztály) gyúitjük ki azokat a közvetlen költségeket, amelyek elhatárolhatók egy termékre (ezért érdemes a költségek költségnemek szerinti vezetése az eredménykimutatást forgalmi költség eljárással készítốk számára is). Ezek alapján az általam javasolt kalkulációs séma és a kalkulációs tételek tartalma az alábbi (Sabján - Sutus, 2003 és Béládi - Kertész, 2005 szintézise alapján):

1. Közvetlen anyagköltség:

a) vetőmagköltség, mútrágyaköltség, növényvédőszer-költség,

b) vásárolt felhasznált növendék-, hízó- és egyéb állatok bekerülési értéke, takarmányköltség,

c) egyéb felhasznált vásárolt és saját termelésú készletek értéke;

2. Igénybe vett szolgáltatások és egyéb szolgáltatások értéke:

a) öntözési költség, szárítási költség, közvetlen fútési költség,

b) állategészség-ügyi költség, teljesítményvizsgálat költsége,

c) idegen gépi szolgáltatások költsége, fenntartó tevékenységek költsége,

d) közvetlen biztosítási és marketingköltség, hatósági igazgatási, szolgáltatási eljárási díj,

e) egyéb szolgáltatások;

3. Közvetlen bérköltség (pl. munkabér, illetve jutalmak);

4. Személyi jellegû egyéb kifizetések;

5. Bérjárulékok (pl. munkabér közterhei, illetve a foglalkoztatottak száma alapján megállapított egyéb adók);

6. Értékcsökkenési leírás;

7. Egyéb költségek:

a) segédüzemi költségek,

b) közös költségek,

c) különféle egyéb költségek (pl. bírságok, kötbérek, késedelmi kamatok, kártérítések, termékpálya-szabályozáshoz kapcsolódó - a terméktanácsok javára teljesített - befizetések, helyi önkormányzati hozzájárulások);

8. Le: növénytermesztés káreseményei miatt elszámolt összeg;

9. Közvetlen költség összesen

$(1+2+3+4+5+6+7-8)$; 
10. Le: melléktermék értéke;

11. Fôtermék közvetlen költsége (9-10);

12. Fốtermék közvetlen önköltsége $(\mathrm{Ft} / \mathrm{t})$.

Sajátos területe a mezôgazdasági önköltségszámításnak az állatok élőtömeg-kalkulációja. Azoknál az állattenyésztési ágazatoknál, amelyeknél a footermék, vagy legalább az egyik fótermék a tömeggyarapodás, az állatok élőtömegének önköltségét is ki kell számítani. Az élótömeg-önköltség azt mutatja, hogy az adott kalkulációs egységnél a kalkulációs időszak végéig felnevelt állatok összes tömegének költsége mennyi volt, beleértve a kalkulációs egységhez kerülés előtt felmerült költségeket is (Miklósyné Ács - Sztanó, 1990). Ez gyakorlatilag az állatok születésétôl kezdôdôen tartalmazza mindazokat a költségeket, amelyek az állatok végtermékké válásáig felmerültek. Például a hízómarha élótömeg-önköltsége tartalmazza a született borjú alomsúlyának önköltségét, az itatásos borjú ránevelt élootömeg-önköltségét, a növendékmarha ránevelt élôtömeg-önköltségét és a marhahízlalásban elért tömeggyarapodás önköltségét. A növendék, hízó- és egyéb állatok élőtömeg-önköltségének kiszámításához az alábbi sémát ajánlom (Sabján - Sutus, 2003 feldolgozása alapján):

1. Nyitó állomány (értékelés: az előző idôszak élőtömeg-önköltségén);

2. Növekedés vásárlásból (értékelés: tényleges beszerzési áron);

3. Növekedés korosbításból és hízóba állításból (értékelés: mindig az előzô - átadó - állománycsoport élôtömeg-önköltségén).

4. Tenyésztésból kiselejtezett és hízóba állított állatok (értékelés: aktuális piaci értéken).

5. Szaporulat, tömeggyarapodás (értékelés: közvetlen önköltségen);

6. Élőtömeg és az arra jutó összes költség $(1+2+3+4+5)$;

7. Élőtömeg-önköltség: (6. sor összeg [Ft] / 6. sor tömeg $[\mathrm{kg}]$.

A fenti séma szerinti élőtömeg-önköltség megállapítását állománycsoportonként a korosbítás (például szarvasmarhánál elôször az itatásos borjúnevelés, majd a növendékmarha-nevelés, végül a marhahizlalás) sorrendjében kell elvégezni.

\section{A vezetối számvitel alkalmazásának szükségessége és az oktatás szerepe}

A vezetôi információk gazdasági értéke a mezőgazdaságban abból a tényból ered, hogy a gazdálkodóknak korlátozott idejük van a gazdaság hosszú és rövid távú célkitúzéseihez meghozott döntéseikre (Simon, 1979). Fontos, hogy a gazdaságok vezetôi - itt leginkább a középméretû́ vállalkozások vezetôire gondolok - saját maguk is belássák, hogy a gazdálkodás gazdasági-szervezési vonalon való javításával olyan komparatív elônyökhöz juthatnak, amelyek lehetôvé tehetik számukra az eróforrásokból való kevesebb felhasználást, a munkaerő kedvezőbb kihasználását, a költségmegtakarítást, így a nyereségesség hosszú távon való növelését. Ez utóbbinak és a vállalkozással kapcsolatos tervezhetôségnek, kiszámíthatóságnak köszönhetően pedig újabb hitellehetôségekhez juthatnak, amelyek a gazdálkodás fejleszthetôségét, méretbeli gyarapíthatóságát eredményezik. Ez természetesen a tulajdonos újabb profitszerzési lehetôségeit növeli, ami újabb gazdasági vagy vagyoni fejlôdést vonhat maga után és így tovább. Megéri tehát az idốt és fáradtságot a vállalkozást vezetói információk felhasználásával racionalizálni.

Az alkalmazás szükségességének további hangsúlyozásához vegyük példaként a nálunk fejlettebb országok vállalatait. A nyugat-európai és amerikai mezőgazdasági vállalkozásokban napjainkban már általánosan elfogadott és használt tudományként jelenik meg a vezetôi számvitel, illetve más, a vállalatelemzést és a vállalatirányítást szolgáló ismeretek. Jó példa erre, hogy már az agráregyetemeken is külön tárgyként oktatják a leendő farmereknek, gazdáknak azoknak a szoftvereknek az alkalmazását, amelyek segítségével agrárvállalkozások gazdasági elemzéseit, adatbázis-feltöltését, -kezelését, vezetôi döntéseket támogató információk létrehozását lehet elvégezni. Ezenkívül a gazdák általános jellegú informatikai képzése is erósebb és komolyabb, mint nálunk, amely természetesen nélkülözhetetlen a vezetối számviteli információs rendszerek, vagy bármilyen más, a menedzsment céljára szolgáló információs rendszer múködtetéséhez.

Véleményem szerint a magyarországi agrárvállalkozásokban a vezetói számvitel alkalmazásának elmaradottsága nem független - többek között - az oktatás jellemzóitól. Nehéz persze megmondani, hogy mi voltelóbb a tyúk vagy a tojás. Hiszen az agrár-felsőoktatás helyzetére nagy hatással van a lassan két évtizede tartó agrárgazdasági válság, valamint az agrárszektor általános feltốkésítésének és kellő jövedelemtermelóképességének hiánya is negatívan befolyásolja az innovációs folyamatokat. A hazai agrár-felsőoktatásban ezenkívül több olyan jelenségnek is tanúi lehetünk, amelyek kedvezôtlenül hatnak az innovációra:

- a felsőoktatási intézményekbe kerülók hányadának növekedése miatt egy átlagos hallgató felkészültsége nem éri el a korábbiakét, 
- míg régebben az egyetemre való törekvésre való motiváltság fớ oka az értelmiségi háttér volt, ma a család anyagi háttere a meghatározó elem,

- a kistelepüléseken élő fiatalok esélye kisebb arra, hogy a felsóoktatási intézményekben megfeleló és arányos képviseletük legyen.

Innováció híján nem várhatjuk, hogy az egyetemrôl kikerülő fiatalok azonnal olyan korszerú vállalatirányítási eszközöket használjanak gazdaságaik vezetéséhez, amelyekról azelőtt sehol sem hallottak. Ezek nélkül pedig könnyen lemaradhatnak agrárvállalataink az EU-csatlakozás miatt kiélesedett versenyben. Megfigyelhetô a nemzetközi trendek tükrében, hogy az utóbbi évtizedekben azok az országok a legnagyobb nyertesei az agrár-világkereskedelmi versenynek (USA, Ausztrália, Új-Zéland), ahol nagyon erós és fejlett az agrárkutatási, oktatási és szaktanácsadási tevékenység és intézményhálózat (Horn, 2002). Egyfajta megoldás lehet, hogy az uniós források hozzáférhetősége miatt kibővült az oktatás és a kutatás fejlesztésére igénybe vehető források köre. Elengedhetetlen azonban - még a potenciális források igénybe vétele előtt - egy átfogó, versenyképes, célorientált innovációs programterv megléte.

\section{Összefoglaló gondolatok}

A mezőgazdaságban az utóbbi évtized gazdasági változásainak következményei nagymértékben befolyásolták a vezetés múködésének feltételeit. A vállalati méretek differenciálódása, a mikro-, kis- és közepes méretû́ vállalatok számának növekedése, a termelési szerkezet egyszerúsödése, a vezetési szintek csökkenése, a tulajdonosi pozíciók erôsödése, a piacgazdasági környezet folyamatos változása mind olyan hatások, amelyek a vezetési feladatokat is befolyásolják, illetve folyamatosan módosítják (Berde, 2003). Ez nem azt jelenti, hogy a mezőgazdasági vezetôk teendối között új feladatok jelentek volna meg, hiszen a teljes üzemgazdaságtan eddig is magába foglalta az ökonómiai, a szervezési és a múszaki-gazdasági ismeretek összességét, amelyek együttes alkalmazása adhat csak választ a komplex üzemszervezési kérdésekre (Székely, 1990; Erdei, 1962). Én inkább úgy fogalmaznám meg, hogy a vezetôk elméleti feladatköre sem változott az elmúlt években, azonban az elméleti feladatok megvalósításához manapság olyan módszerek, eszközök állnak rendelkezésre - ilyen például a vezetôi számvitel -, amelyek alkalmazása „kötelezőnek" mondható a vállalkozások vezetôi számára a jelenlegi piaci versenykörülmények között.
Az Európai Unióhoz való csatlakozásunk, és ebból kifolyólag az FADN-adatbázis és a tesztüzemi rendszer gyakorlatban való használata még aktuálisabbá teszi a kérdéskört. Az információs rendszerekbe szolgáltatott és az azokból nyerhetô, vezetôi számviteli információs jellegú adatok jó alapként szolgálhatnak a vezetói számviteli elemzésekhez. A rendszerból származó adatok ilyen célra való felhasználásának kedvező hatásait a hosszú távú nyereségességre és a vállalat növekedésére, többek között, a fent említett holland tudományos kutatás is igazolta. Tisztán kell azonban látnunk azt is, hogy csupán a vezetói számvitel alkalmazása nem ad teljes körú megoldást a vezetốk feladatainak ellátásához. A vállalaton belül múköoő összes információs csatornával együtt tudnak létfontosságú alapot nyújtani a tervezéshez, a döntéshozatalhoz, a szervezéshez és az ellenőrzéshez.

Fontos feladat a gazdák ellátása olyan elméleti és gyakorlati ismeretekkel, amelyek lehetővé teszik számukra a vezetói számvitel, illetve az ahhoz hasonló modern vállalatirányítási módszerek alkalmazását. Ezen a téren bátran vehetünk mintát a tólünk nyugatra fekvő országoktól, például egy vezetôi számviteli szoftver használatának oktatása formájában. Mindezek alapfeltétele az agráregyetemeken való oktatás megreformálása, illetve a képzésben elérhetô tantárgyak kibővítése hasonló témakörú alapozó tárgyakkal.

\section{Felhasznált irodalom}

Berde Cs. (2003): Menedzsment a mezőgazdaságban. Budapest, Szaktudás Kiadó Ház

Béládi K. - Kertész R. (2005): A tesztüzemek fóbb ágazatainak költség- és jövedelemhelyzete 2004-ben. Budapest: Agrárgazdasági Kutató Intézet

Csajbók I. - Lansink A.O. - Huirne R. (2005): Effects of management information from FADN on profitability of Dutch potted-plant firms. Agricultural Economics, 2005. 3. pp. 325-332.

Engler, C. (1990): Managerial accounting, 2. ed. Homewood, Boston: Irwin

Erdei F. (1962): A termelőszövetkezeti üzemszervezés gyakorlati kézikönyve, 2. átd. bóv. kiad. Budapest: Akadémiai Kiadó

Erdei F. (1965): Önköltség a szocialista mezőgazdaságban. Budapest, Akadémiai Kiadó

Grimshaw, K. (1993): Vezetôi számvitel - magyarországi tapasztalatok. Számvitel és Könyvvizsgálat, 9. pp. 394-397.

Horn P. (2002): Az agrár-felsőoktatás és kutatás stratégiai kérdései nemzetközi trendek összefüggésében. Gazdálkodás, 46. 1. pp. 1-7.

Kapronczai I. (2003): Agrárinformációs rendszerek fejlesztésének megalapozása, PhD-értekezés. Gödöllő 
Keszthelyi Sz. - Kovács G. - Dobolyi E. (1998): A tesztüzemi hálózatban részt vevô gazdaságok 1997. évi eredményei, Agrárgazdasági Kutató és Informatikai Intézet. Agrárgazdasági információk, 1.

Kittredge, J. (2004): Process management and Cost management: collaboration or opposition? Cost management, 2004. 5. pp. 23-30.

Kovács G. (2001): Adatszolgáltató mezôgazdasági üzemek az EU információs rendszerében (FADN). Gazdálkodás, 45. 6. pp. 63-66.

Körmendi L. - Tóth A. (2002): A controlling tudományos megközelítése és alkalmazása. Budapest, Perfekt Gazdasági Tanácsadó, Oktató és Kiadó Rt.

Laáb Á. (1998): Pénzügyi számvitel menedzsereknek. Budapest, Kossuth Kiadó

Lucey, T. (1996): Management Accounting. London, DP Publications

Miklósyné Ács K. - Sztanó I. (1990): Mezőgazdasági vállalkozások költség-, önköltségszámítása. Budapest, Pénzügyi és Számviteli Fốiskola

Nagy G. (Szerk.) (1993): A vezetôi számvitel - A számvitel a vezetés szolgálatában. Számvitel és Könyvvizsgálat, 35. 7-8. pp. 313.
Sabján J. - Sutus I. (2003): Vezetôi számvitel az agrártermelésben. Budapest, Szaktudás Kiadó Ház Rt.

Simon, Herbert A. (1979): Rational decision making in business organisations. American Economic Review. 69, pp. 493-513.

Stone, John A. (1968): Accounting for management in agriculture. Sydney, Angus and Robertson Ltd.

Sutus I. (1992): Mezőgazdasági önköltségek számítása. Számvitel és Könyvvizsgálat, 34. 2. pp. 57-60.

Székely Cs. (1990): Menedzsereket a mezőgazdaságba? Gazdálkodás, 34. 7. pp. 66-71.

Véry Z. (2001): Mezôgazdasági üzemek korszerú irányítása. Gazdálkodás, 45.1. pp. 25-32.

A 79/65/EEC (VI. 15) számú Tanácsi rendelet. Council Regulation about setting up a network for the collection of accountancy data on the incomes and business operation of agricultural holding sin the European Economic Community (Official Journal P 109, 23.06.1965, p. 1859

A 2000. évi C. törvény a számvitelról. Kihirdetve 2000. szeptember 21-én a Magyar Közlönyben.

Cikk beérkezett: 2007 . 7. hó

Lektori vélemény alapján átdolgozva: 2008. 2. hó

\section{E SZÁMUNK SZERZŐI}

Dr. Hoványi Gábor, akadémiai doktor, habilitált egyetemi magántanár, Pécsi Tudományegyetem; Borgulya Istvánné Vetố Ágnes, CSc egyetemi docens, Pécsi Tudományegyetem; prof. Angyal Ádám, egyetemi tanár, Budapesti Corvinus Egyetem; Jánosi Gergely, PhD hallgató, Budapesti Corvinus Egyetem; Kersch Gabriella, PhD hallgató, Budapesti Corvinus Egyetem; Zárda Nóra, PhD hallgató, Szent István Egyetem, Gödöllő; Szabó

Zsolt Roland, PhD hallgató, Budapesti Corvinus Egyetem 